\title{
Term and Legal Position of an Individual Entrepreneur in Republic of Serbia
}

\section{Markovic V., \\ E-mail:vmarkovic@singidunum.ac.rs}

Vicentijevic K., kvicentijevic@singidunum.ac.rs

Petrovic Z., zpetrovic@singidunum.ac.rs

\section{Correspondence: kvicentijevic@singidunum.ac.rs}

\begin{abstract}
An entrepreneur is a business-able physical person who performs activities to gain the profit and who is registered according to law. Starting from the national and theoretical and legal solutions and court practice from comparative law, the authors analyze the concept and the legal position of an individual entrepreneur noticing the problems and inconsistencies in legal regulations.

The authors of the work make a few conclusions and suggestions: 1) terminology is not coordinated with legal terminology from comparative law. In our law, the legal term is "entrepreneur", which is a too wide and unspecified term because in economic profession this term represents the genus term for individual and collective entrepreneurship; 2) analyze all forbidden activities for entrepreneurs, judge the reasons pro et contra and work on eliminating prohibitions and favoring legal entities; 3) set by law the bankruptcy of an individual entrepreneur i.e. the individual bankruptcy of a physical person; 4) work on passing a separate legislation in the field of the individual entrepreneurship, especially on passing and changing the laws which would regulate handicrafts (including old crafts and jobs of home industry), free professions as well as agricultural activity.
\end{abstract}

Keywords: entrepreneur, individual entrepreneur, sole proprietor, economic subject.

\section{Introduction}

A $\mathrm{n}$ individual entrepreneur, as a legal form of business operations, is very important in our legal system. Firstly, because of the number of registered entrepreneurs and secondly because of a great number of persons employed by entrepreneurs. In table 1 there is a comparative review of registered business enterprises and entrepreneurs, i.e. economic entities. by its legal type or form. In our legal system, the legal position of an individual entrepreneur is set by Law on economic entities, "Official Herald of Serbia", no. 36/2011, 99/2011, 83/2014, 5/2015, only by principal provisions and suitable application of certain provisions about economic entities. There is missing a separate law which would regulate the legal position of an individual entrepreneur and, on the other hand, there is a small number of scientific works written in this field.

Table 1.

The number of registered active economic entities, entrepreneurs and the total number of registered active economic entities in last five years Source: SBRA (2015)

\begin{tabular}{|c|c|c|c|}
\hline Year & $\begin{array}{c}\text { Number of registered } \\
\text { active economic entities }\end{array}$ & $\begin{array}{c}\text { Number of registered active } \\
\text { entrepreneurs }\end{array}$ & $\begin{array}{c}\text { Total number of registered } \\
\text { active economic entities }\end{array}$ \\
\hline 2014. & 115692 & 215367 & 331059 \\
\hline 2013. & 110952 & 212716 & 323668 \\
\hline 2012. & 105105 & 218127 & 323232 \\
\hline 2011. & 104723 & 220458 & 325181 \\
\hline
\end{tabular}

In developed economies, as well as in our country, the largest number of economic entities start business in legal-organizational form of an individual entrepreneur (sole proprietor, craftsman, some form of free profession or some other form). The legal position of an individual entrepreneur (set of subjective rights and legal duties which a legal subject may have [30]) is primarily defined
Out of the mentioned reasons, starting from the local and foreign theoretical and legal solutions, the economic and legal understanding, noted problems in the practice, the authors want to contribute by this work to a better understanding and comprehending the concept and the legal position of an individual entrepreneur with the suggestions for improving the legal regulating. 


\section{Theoretical concept of an individual entrepreneur}

An entrepreneur (merchant) is a legal form of organizing a company for performing a certain activity to gain a profit, under, according to rule, the individual (personal) business name by the physical person and with unlimited liability with his complete assets. The sole proprietor - entrepreneur may solely be a physical person (which has a business ability) and not a legal entity ${ }^{1}$.

In comparative law, physical persons who perform an economic activity as a permanent profession (England: Sole proprietor, in USA: Individual proprietorship, Germany. Kaufmannn) represented first historical form of subjects who as buyers or sellers, i.e. as sole proprietors, performed the trade activity. These persons, according to the decisions from the law in most countries, were only asked to be registered in special trade registeres to perform trade activities under their name (without establishing a separate legal entity). The most liberal system is scheduled by the law in USA, according to which no registration is necessary, except when the person who plans to deal with so called licenced work or if he intends to appear in the legal transactions under the firm which is different from his name ${ }^{2}$.

The sole or single proprietorship is a business structure for a firm that is owned and operated by one person. This means it is the easiest legal structure to set up, and it is also the most used form of small business legal structure ${ }^{3}$.

The sole proprietorship is a popular business form due to its simplicity, ease of setup, and nominal cost. A sole proprietor need only register his or her name and secure local licenses, and the sole proprietorship is ready for business ${ }^{4}$.

Sole proprietorship: Unincorporated business that is run by one person on his or her own. The sole proprietor of a professional practice (such as an accountant or solicitor) is known as a sole practitioner. The sole proprietor of another type of business is generally known as a sole trader ${ }^{5}$.

Sole trader is person who trades on his or her own behalf and has not registered as a business.

In the financial and stock exchange worlds, however, the term has three precise meanings:

Vasiljević, M. Kompanijsko i trgovinsko pravo (ISBN 97886-519-0046-7). Pravni fakultet Univerziteta u Beogradu i JP Službeni glasnik Beograd, 2008.

2 Vukadinović, R. Međunarodno poslovno pravo (ISBN 978 86-88987-03-5). Udruženje za evropsko pravo, Kragujevac, 2012.

Cohen, W. A. Entrepreneur and Small Business Problem Solver. John Wiley \& Sons, 2006.

4 Spadaccini, M. Business Structures: Forming a Corporation, LLC, Partnership, Or Sole Propretorship. Entrepreneur Press, 2007.

Clark, J. i Owen E. ed. Dictionary of International Accounting Terms. Global Professional Publichi, 2001.
1. It is a trader involved in buyng and selling securitities short-term, for his or her own account.

2. It is somebody who specializes in buying and selling securities on behalf of a broker or dealer, usually working as an employee.

3. It is a person who buys and sells contracts in financial futures without a hedge in the appropriate cash market ${ }^{6}$.

In local legislation, there was not taken a necessary care that the concept „entrepreneur" in economic sense represents a genus concept for individual and collective entrepreneurship and there is not the standardization of the concept of individual entrepreneurship, i.e. a sole proprietor. In comparative law and legislation, there are used different names for physical persons who perform an activity as a profession in order to gain a profit: merchant, sole proprietor, individual merchant, complete merchant, individual entrepereneur and so on. Our legal system uses the term entrepreneur ${ }^{7}$.

In German legislation ${ }^{8}$ : an entrepreneur is named as „merchant“ or „registered merchant“ (eingetragener Kaufman EK, E.KFM or female: e.Kfr). If an entrepreneur reaches the annual turnover of 250.00o Euro, he must be entered in Commercial register. If he has a smaller annual turnover, the registration is voluntary. German commercial law (HGB) is applied on a registered merchant ${ }^{9}$.

In Belgium, an entrepreneur is known as an individual entrepreneur (eenmanszaak/L̇Entreprise Individuelle) and he is also completely liable with all assets and there is not the difference between private assets of the owner and the entrepreneur's assets. He has the legal obligation to be registered at Kruispuntbank Van Ondernemingen (KBO)/ Bankue Carrefour des Entreprises (BCE) as well as in Fund of social security ${ }^{10}$.

In Switzerland, they use the term „Einzelunternehmen“ for an entrepreneur and it is a physical person who performs business activity on his behalf and on his responsibility. He has the complete unlimited responsibility for liabilities, including also the private assets. An entrepreneur in Switzerland is

\footnotetext{
Clark, J. i Owen E. ed. Dictionary of International insurance and finance terms. Global Professional Publichi, 2001.

Dabić, Lj. Individualni preduzetnik kao privredni subjekt i kao poseban pravnoorganizacini oblik, Pravo i privreda, Udruženje pravnika u privredi, Beograd, 2005, vol. 42(5-8), pp. 164-185.

8 Commercial Register from Germany/CRG: Legal forms in Germany, available at: http://www.commercial-register.com/ legalformsgermany.html accessed on October 03, 2016.

Chambers of Commerce Euregio Meuse-Rhine/ CCEMR: Database of legal entities, available at: http:// www.euregiochambers.eu/legal-enities/germany/soleproprietorship.html, accessed on October 03, 2016.

Chambers of Commerce Euregio Meuse-Rhine/ CCEMR: Database of legal entities, available at: http:// www.euregiochambers.eu/legal-entities/belgium/soleproprietorship.html, accessed on Octobre 03, 2016.
} 
very often the first step towards self- employment. The business name of an entrepreneur must include the surname of the owner as the main component. An entrepreneur must be registered in the trade register if he has the annual turnover of 100.00o CHF and if the turnover is smaller, the registration is voluntary. In each case, the entrepreneur must be given the status of a self-employed person. Social security stands that a physical person is self-employed if he works on his own behalf and for his benefit, has an independent position, bears his own economic risk. Office for social security in Zürich deals with recognizing self-employment ${ }^{11}$.

The legislation in Slovenia (Zakon ogospodarskih družbah, «Uradni list Republike Slovenije», 42/2006), for a physical person who individually performs an activity in order to gain a profit, uses the term "independent individual entrepreneur" (samostojni podjetnik posameznik), who is named by the legislator "entrepreneur" (podjetnik) in short.

In Croatia they use the term "sole proprietor" besides the general term "merchant" (Law on trade enterprises, «Narodne novine Hrvatske», no. 111/1993, 34/1999, 52/2000, 118/2003, 107/2007, $146 / 2008,137 / 2009,125 / 2011,152 / 2011,111 / 2012$, $68 / 2013$, article 3. paragraph 1). A merchant is a legal entity or a physical person who independently and permanently performs an economic activity to gain a profit by production, turnover of goods or performing services on market. A sole propreitor is a physical person who individually performs the economic activity in accordance to regulations about turnover and who is registered in court register as a sole propreitor. A physical person who does business in accordance with regulations about the turnover, may ask to register himself in the court register as a sole propreitor if his annual turnover exceeds the amount ot two million kunas and he is obliged to ask to be registered if his annual income exceeds the amount of 15 million kunas.

In Macedonian law (Zakon za trgovskite društva, «Službeni vesnik na Republika Makedonija», no. 28/2004, 84/2005, 71/2006, 25/2007, 87/2008, $17 / 2009,23 / 2009,42 / 2010,48 / 2010)$ they use the term "single merchant" (trgovec-poedinec). A single merchant is a physical person whose profession is to perform a commercial activity set by law.

In domestic legal theory, there have long been demands to rename the term entrepreneur. Some authors think that the term entrepreneur should be renamed in "individual businessman"12, others in the

\footnotetext{
Gruenden: Step by step to your own company, Legal structure - sole proprietorship, available at: http://www. gruenden.ch/en/founding-process/preparation/legal-forms/ sole-propretorship / accessed on October 03, 2016.

12 Spirović Jovanović, L. Trgovac pojedinac, preduzetnik ili individulani privrednik, Pravni život, Udruženje pravnika Srbije, Beograd. 1996, vol. 45(11), pp. 145-157.
}

term "sole propreitor" ${ }^{13}$, the third most often use the term "individual entrpreneur (merchant)" 14 .

We agree with the opinion ${ }^{15}$ that the term entrepreneur should be renamed into the term "individual entrepreneur" or "single entrepreneur". In that way, a physical person as a registered economic entity would differ by the name from the general, genus and economic term "entrepreneur".

\section{Legal concept of an individual entrepreneur}

Legal position of an entrepreneur in domestic law is set by Law on economic enterprises (hereinafter: LEE). According to article 83 in LEE, an entrepreneur is a business-able physical person who performs activities to gain the profit and who is as such registered according to law on registration. An entrepreneur may not be a legal entity.

For performing the individual activity, an entrepreneur establishes a shop, i.e. a suitable form of business (workshop, office, bureau, service, agency, studio, boarding house, pharmacy, doctor's surgery and the like).

If a physical person wants to be an entrepreneur, the following legal conditions have to be met:

1. the physical person must be business-able;

2. the physical person must perform a certain activity;

3. he must perform the activity in order to gain a profit;

4. he must be registered in accordance to law on registration.

The basic condition for a physical person to become an entrepreneur is the business ability. Business ability is the possibility of a physical person to set, change and cancel rights and liabilities on his own will. This ability is primarily shown in the ability of a physical person to conclude, change and cancel legal business, because of which it is called "business ability". A physical person gains the complete business ability when he becomes of age (is 18 years old) and by signing a marriage, upon the court permission, when he is 16 . Besides that, a child may gain business ability before legal age, when he is 16 , if he /she became a parent and if he/she reached the body and spiritual maturity for the individual care about own personality, rights and interests, upon the court permission ${ }^{16}$.

\footnotetext{
Milenović, D. Entrepreneur (Individual Tradesman) in Our Law, Pravni život, Udruženje pravnika Srbije, Beograd, 2002, vol. 51(11), pp. 81-92.

Vasiljević, M. Vodič za primenu Zakona privrednim društvima (ISBN 978-86-83437-96-2), Intermex, Beograd, 2011.

Dabić, Lj. Individualni preduzetnik kao privredni subjekt i kao poseban pravnoorganizacini oblik, Pravo i privreda, Udruženje pravnika u privredi, Beograd, 2005, vol. 42(5-8), pp. 164-185.

16 Babić, I. Građansko pravo, Knjiga 1. Uvod u građansko pravo (ISBN 978-86-519-1028-2), JP Službeni glasnik i Fakultet za evropske pravno-političke studije, Beograd - Novi Sad, 2011.
} 
A physical person registered in a special register, who performs the activity of a free profession set by separate rules, is considered as an entrepreneur in terms of Law on commercial enterprises, if it is set by those rules. A free profession is the profession which is as such qualified and defined by law - practice of law, public notary practice, health services, engineering, auditing, tax counselling, actuary, art, journalism, veterinary and others. For example, in our legislation there is given a legal definition of health service as a free profession through its performing: „to perform a profession, in terms of law, means the direct performing of health service by medical workers who have a suitable education in health profession and who perform their activity in health institutions and private practice as well as at other employers, under the conditions set by law which regulates the health protection (Law on chambers of medical workers "Official Herald of Serbia, no. 107/2005, 99/2010, article 4, paragraph 3) or in Codex of professional ethics of lawyers „Practice of law is professional performing of lawyer's activity", (in Codex of professional ethics of lawyers „Official Herald of Serbia“, no. 27/2012 article 2, item 3.1.1.). More about free professions ${ }^{17}$.

An individual farmer is not an entrepreneur in terms of this law, except when it is set in a different way by a special law. He obtains the status of an entrepreneur and he has the obligation to keep business books:

a. if the bearer of a registered agricultural holding (voluntary) chose to have the status of an entrepreneur by submitting the tax application to the competent tax authority (In Register of agricultural holdings there are registered commercial enterprises, agricultural cooperatives, other legal entities like institutions, schools, monasteries, churches and other organizations, entrepreneurs and farmers who perform agricultural production from article 20 , paragraph 1 in Law on agriculture and rural development, „Official Herald of Serbia“, no. 41/2009 and 10/2013 - another law);

b. if the registered agricultural holding is the tax payer on value added tax (VAT). The farmer whose total turnover of goods and services in the prior 12 months does not exceed 8.0oo.ooo RSD, does not count VAT for the performed turnover of goods and services. An entrepreneur may choose to pay VAT by submitting the registration form, set in accordance with law, to the competent tax authority and in that case he obtains the rights and liabilities which a payer of VAT has by law (Article 34, paragraph 5 and 6 in

\footnotetext{
17 Dabić, Lj. Pojmovno određenje i svojstva slobodnih profesija, Pravni život, Udruženje pravnika Srbije, Beograd, 2008, vol. 57(12), pp. 473-489.
}

Law on value added tax, „Official Herald of Serbia“, no. 84/2004, 86/2004, 61/2005, 61/2007, 93/2012, 108/2013, 6/2014, 68/2014, $142 / 2014,5 / 2015)$.

However, by entering in Register of economic entities, an entrepreneur does not obtain the status of legal entity but he keeps the status of a physical person. By entering in the register, an entrepreneur obtains the status of economic entity and some characteristics of a legal entity. Court practice: „A party in the proceedings, which arise in connection with the business transactions and activity of the shop, may only be a physical person as the owner i.e. the founder of the shop and not the shop as it does not have the status of a legal entity but certain characteristics of a legal entity. As a shop does not have its own legal subjectivity, it may not be the bearer of rights and obligations and thus it cannot be a party in proceedings", from the decision of District Court in Novi Sad, Gž. 1055/05 on 11.05.2006. So, „A party in proceedings may be a physical person, as an entrepreneur and shop owner, but it may not be the shop", from the decision of Supreme Court of Serbia, Prev. 34/o1 and Pzz. 2/o1 on 07.02.2001. The elements of legal subjectivity of a legal entity which an entrepreneur has: business name, head-office, activity and others ${ }^{18}$.

The entrepreneurship status of a physical person does not affect his legal subjectivity obtained by birth, like it is not affected when the status stops because of deletion. All physical persons are legal entities and some of them are economic entities. A physical person - entrepreneur is an economic entity and as such he is registered according to Law on the registration of economic entities (from the decision of District Commercial Court, Pž. 9249/o7 on 03.04.2008).

For all liabilities which arise in connection with performing his activity, an entrepreneur is liable with all assets and they also include the assets acquired in connection with performing the activity. Court practice: "The assets of a physical person who is an entrepreneur includes rights, claims and funds obtained through the activity for which the shop is registered, but also the rights, claims and funds obtained outside it, form other materially legal relations". The assets of the person are burdened by liabilities which he took over in connection with performing the registered activity, but also the liabilities which were taken over beyond it", from the decision of District Commercial Court, Pž. 9249/07 on 03.04.2008). The responsibility for the mentioned liabilities does not stop by deleting the entrepreneur from the register.

In comparative law: The proprietor is personally responsible for all business losses and must 
bear them to the full extent of available personal resources. The proprietor is personally liable for all business liabilities. In contrast with a corporate shareholder or a limited partner, a proprietor carries a financial risk that is not limited to his or her investment in the enterprise but may extend to all personal assets, including the proprietor's home, car, furniture, and similar property ${ }^{19}$.

The owner is inseparable from the sole proprietorship, so he/she is liable for any business debts; also called Proprietorship ${ }^{20}$.

An entrepreneur may perform the activity outside the head-office (separate place) which is registered in accordance with law on registration. An entrepreneur may also perform the activity outside a certain space (when summoned by a party, from place to place and the like) when, according to the nature of the activity, such performing is only possible and usual.

An entrepreneur performs the activity directly. $\mathrm{He}$ is the bearer of the activity which he performs on his behalf and for his own benefit, with the possibility to do it for somebody else's benefit (for example, an agent). However, an entrepreneur may employ other persons in accordance with labourlegal regulations ${ }^{21}$.

\section{Advantages and drawbacks of an individual entrepreneur}

An entrepreneurship as a form of organizing a legal entity has numerous advantages and flaws. In comparative law $^{22},{ }^{23}, 24$, there are mentioned the advantages and drawbacks of entrepreneurs which coincide with the position in our legislation.

Advantages of an entrepreneur, as a legally organizational form, are:

1. Ease and speed of organizing. There are less formalities and legal limitations.

2. Small expenses of starting business. There is a minimum compensation for the registration and a small legal help necessary to set up and organize this form of business.

3. Complete control. There is not a partnership or other owners to consult them. The owner has a total control over business and he may

\footnotetext{
19 Moye, J. The Law of Business Organizations. Cengage Learning, 2004.

20 Masoom, K. The Entrepreneur's Dictionary of Business and Financial Terms. PartridgeIndia, 2013.

21 Milenović, D. Entrepreneur (Individual Tradesman) in Our Law, Pravni život, Udruženje pravnika Srbije, Beograd, 2002, vol. 51(11), pp. 81-92.

22 Cohen, W. A. Entrepreneur and Small Business Problem Solver. John Wiley \& Sons, 2006.

23 Spadaccini, M. Business Structures: Forming a Corporation, LLC, Partnership, Or Sole Propretorship. Entrepreneur Press, 2007.

24 Gill, J. Business Law for the Entrepreneur. Arima Publishing, 2005
}

start it in the manner which suits him best. The owner makes all decisions. There are no boards or directors or any other chiefs, besides buyers, to advise him, tell him what to do, to supervise his decisions or to criticize his faults. As the result, the founder may quickly respond to business demands. Victory, defeat or retreat is his own show, and everything he says may happen.

4. The only recipient of the profit because he is the only one and he does not need to share the profit with anyone.

5. Relative freedom concerning tax liabilities and regulations.

6. The owner may freely mix business and personal assets.

7. Cessation of performing activity. Cessation of work is also very easy. The owner may liquidate his assets, pay his debts, turn off the light and his complete undertaking is turned off.

Drawbacks of an entrepreneur, as legally organizational form, are:

1. Unlimited responsibility. The main drawback of an entrepreneur is that the owner has the unlimited personal responsibility in his work. It means that he is responsible for the total amount of business debts by his personal assets like a house or a car. If the business fails while he gets into debts at various creditors, those money funds which he borrowed may be taken from his personal assets.

2. Complete dependence on personality. An entrepreneur's job is done, by rule, by one person who is limited by his skills and capacities. It means, for example, that he may not be able to go to holiday or the company will be in danger because of a serious disease or anything that keeps him off work for a long period of time.

3. Difficulties with capital. As he is the only person, there may be more difficulties to get a loan for the work than for other forms of economic entities where more people are involved. Being an entrepreneur is the hardest form of organizing a company when it comes to finances.

4. Suitable for a smaller scope of work.

\section{Business name}

An entrepreneur performs the activity under the business name. The business name of an entrepreneur must contain name and surname of the entrepreneur, the description of the predominant activity, the designation „entrepreneur" or "pr“ and the head-office. In Germany, the business name usually contains the complete name of the owner. It is usually combined with the business contents. 
Besides that, the owner has the right to freely choose his name. It should be added „registered merchant"or ",ek" (\$19 HGB), (RW 2014) in the name. In Croatia, the business name of a sole proprietor must contain his name and surname. The business name (company) of a sole proprietor must contain the designation "t.p." (article 24 in Law on trading companies in Croatia).

An entrepreneur could not perform his activity under the business name which is not entered in the register of economic entities and the business name could not be entered in the register of economic entities if it does not contain all elements set by Law on commercial enterprises.

Besides that, the business name of an entrepreneur, besides the elements which it must contain, may also contain a special name and designations which determine the subject of business ("Firm, name of commercial enterprise may be used as a stamp and then it is graphically represented in a certain form. The economic entity then has the protection of the firm on the basis of the legal regime which is applied on the protection on stamps, and unauthorized use of such stamp under certain conditions represents unfair competition", from the verdict of District Commercial Court, Pž. $761 / 2008$ on 17.10 .2008 ).

A sole proprietorship can operate under the name of its owner or it can do business under a fictitious name, such as Nancy's Nail Salon. The fictitious name is simply a trade name - it does not create a legal entity separate from the sole proprietor owner 25 .

The business name of the entrepreneur does not have to contain the name.

In legal transactions, an entrepreneur must use the business name as it is entered in the register of economic entities („There is not the effect on the party ability of the entrepreneur if there is first given the name of the shop and then the personal name of the entrepreneur or vice versa", from the verdict of Commercial Court of Appeals, Pž. 4844/13 on 16.01.2014).

The business name of the entrepreneur must be different from the name of another entrepreneur so that it does not cause the misapprehension about the identity with another entrepreneur, i.e. the misapprehension in terms of the subject of entrepreneur's business transactions (article 86, paragraph 3, LEE).

\section{Showing business name}

Pursuant to the provision in article 87 , paragraph 5 in LEE, an entrepreneur is obliged to show his

\footnotetext{
25 Spadaccini, M. Business Structures: Forming a Corporation, LLC, Partnership, Or Sole Propretorship. Entrepreneur Press, 2007.
}

business name in his head-office as well as on each separate place, except when he performs the activity outside a certain space (when summoned by a party, from place to place and the like) when, according to the nature of the activity, such performing is only possible and usual.If he does not show the business name in his head-office as well as at another place where he performs the activity, the entrepreneur will be fined for the offence with the amount from 50,000.00 RSD to 200,000.00 RSD, pursuant to the provisions in article 588, paragraph 1, item 3 in LEE.

The regulations also set the obligation of showing the business name on the vehicles of economic entities. On the basis of the provisions in article 5 in Law on transport in road trasnportation, „Official Herald of Serbia“, no. 46/95, 66/20o1, $61 / 2005,91 / 2005,62 / 2006,31 / 2011$, the bus which is used for the transport of passengers in road transportation, except the bus which is ised for the city-suburban transport of passengers, must have on its sides written business name, i.e. firm, and it may have its sign which is protected in accordance with law which sets stamps. A freight vehicle which is used for the transport of goods in road transportation must have on side door, i.e. on the sides of the vehicle cabin, written business name, i.e. firm, and it may have its sign which is protected in accordance with law which sets stamps.

A car owned by a physical person and which he uses for his personal needs, a car of an economic entity used for transport, vehicles which are used for the training of candidates for drivers and the car which is used as a taxi do not need to have written business name, i.e. firm or its sign on the sides.

On the roof of the vehicle used for the transport of passengers or goods in road transportation, except the car used as a taxi and vehicles which are used for the training of candidates for drivers there may not be put the business name, i.e. firm and there may not be put other inscriptions (artcile 52, paragraph 1, item 1 in Law on transport in road transportation: An entrepreneur will be fined with 150.000 to 500.00o RSD if there is put a firm or other inscription on the roof of the vehicle used for the transport of passengers or goods in road transportation, except the car used as a taxi and the vehicles used for the training of candidates for drivers).

On the sides of a bus, i.e. on the side door or on the sides of the cabin of a fright vehicle there may not be put other inscriptions except the business name, i.e. the sign which is protected in accordance with law which sets stamps.

The business name, i.e. firm must be written on the vehicle by the letters at least $5 \mathrm{~cm}$ high in the colour which is significantly different from the basic colour of the vehicle.

A lease holder and the lessee of a car are considered as the vehicle owner in terms of mentioned rights and obligations. 
With respect to the use of the business name, Law on commercial enterprises sets that business letters and other entrepreneur's documents, including the ones in electronic form, which are sent to third parties have to contain business name or shortened business name, head-office, address for receiving mail if different from the head-office, register number and tax identification number. An entrepreneur is obliged to use the stamp in business letters and other documents if the law does not set it in a different way (article 86 in connection with article 25 in LEE).

\section{Head-office and place where the activity is performed}

The head-office of an entrepreneur is the place from which he directs the performing of the activity (article 87 in LEE). It does not have to be necessarily the place where the activity is performed. An entrepreneur may perform the activity outside the head-office, in accordance with the law (separate place). The separate place is registered in accordance with law on registration. The registration is performed only on the basis of the application and the proof about the fee payment.

The activity has to be determined for the separate place if it is different from the predominant activity in the head-office which the entrepreneur registered.

An entrepreneur may perform the activity outside a certain place (when summoned by a party, from place to place and the like) when, according to the nature of the activity, such performing is only possible and usual.

The place where the activity is performed must meet the requirements set by regulations for performing that activity: technical, personnel and sanitary. Otherwise, there is the fine for the offence of the entrepreneur in the amount from 50.000 to 200.00o RSD (article 588 in LEE).

Technical requirements for the place where the activity is performed. Depending on the activity which an entrepreneur performs, the business premises must meet the requirements set by special regulations for the given activity. For example, the purchase of agricultural products may be performed through purchasing stations which must meet the requirements set by Rulebook about minimal technical conditions for the trade at purchasing places, „Official Herald of Serbia“, no. 72/2011. The purchasing place must have furnished space, facility, a part of the facility, rooms for the receipt and measuring of goods, the space for storage, loading and unloading of agricultural products as well as a separately built or fenced space for the receipt, housing and purchase of domestic animals. At the purchasing place there are applied technical, hygienic and veterinarysanitary conditions for the receipt, measuring, storage, loading and unloading of agricultural products and domestic animals, in accordance with special regulations. The space of the purchasing place must meet the following conditions:

1. land must be dry and drained and surface water should be drained in accordance with technical and hygienic conditions;

2. fecal and other liquid waste materials must be drained in the public sewage system and if there is not any, the drainage should be performed in closed trasnport vehicles to the device for refinement, i.e. to a closed permeable cesspit;

3. solid waste materials must be collected at a specific and arranged place in accordance with regulations about hygienic-technical protection and the environment protection (closed pits and the like);

4. the purchasing place must not endanger the environment by its function (condition of water, soil, air and the like) and it must not complicate normal transportation. It also must meet the conditions set by valid regulations which define the transport of agricultural products and domestic animals;

5. the purchasing place must meet the conditions in accordance with the regulations which set the conditions for the transport of agricultural products and domestic animals.

The room of the purchasing place is built of solid material and it must be dry, airy, with natural or artificial light, protected from humidity and with necessaary ventialtion and it must protect the purchased products from spoilage and decay.

The room of the purchasing place is built of the material which can be easily cleaned, washed and desinfected (concrete or plated by solid material stone, concrete plates, bricks and the like) and it must be maintained regularly.

The purchasing place must have a permanent supply of hygienic correct water, from the public water supply or in another way.

The purchasing place cannot be located near a dump, landfill, unsanitary toilets, open canals, factories which emit gases, vapour, smoke, dust as well as near other facilities which may have a harmful effect on hygienic conditions in the facility, i.e. the hygienic correctness of agricultural products.

The purchasing place must have a hygienically built sanitary facility.

Personnel conditions for performing the activity. Special regulations can set special conditions for an entrepreneur in terms of the number of personal qualifications for performing a certain activity. An employee at an entrepreneur and the entrepreneur himself must meet general conditions and performing of the activity should not be prohibited by the effective court decision 
or an offence decision. For example, in the Rulebook about detailed conditions for performing health care activity in health institutions and other forms of health services, "Official Herald of Serbia", no. 43/2006, 112/2009, 79/2011, 10/2012, 119/2012, 22/2013, there are set detailed conditions concerning the personnel, equipment, space and medicaments which health institutions, i.e. other forms of health service - private practice must meet in order to establish and perform the health activity, i.e. certain jobs in health activity.

Private practice may be established and certain jobs in health activity may be performed if, regarding the personnel, it has:

1. in doctor's surgery - one doctor of medicine; in dentist's surgery - one doctor of dentistry; in a specialist surgery one doctor of medicine, i.e. a doctor of dentistry specialist in the adequate field of medicine i.e. dentistry, and in a specialist surgery in surgical fields of medicine, i.e. dentistry one health worker with college or secondary education;

2. in a polyclinic - three doctors of medicine, i.e. doctors of dentistry of various specializations and two nurses technicians with college or secondary education;

3. in laboratory: for medical i.e. clinical biochemistry - one graduate pharmacist - medical biochemist or a graduate pharmacist specialist of medical biochemistry or a doctor of medicine specialist of clinical biochemistry and two laboratory technicians with college or secondary education; for microbiology and pathohistology: one doctor of medicine specialist in an adequate field of medicine and one laboratory technician with college or secondary education;

4. in pharmacy - one graduate pharmacist;

5. in out-patient's room: for health care - one nurse - technician with college or secondary education and for the rehabilitation - one physiotherapist with college education;

6. in the laboratory for dental technique: one dental technician with college or secondary education.

Sanitary conditions. The employees at an entrepreneur who (as the entrepreneur himself) perform the job of:

1. public supply of citizens with drinking water, production, transport and catering of provisions, except the persons employed in the production of hard alcoholic drinks, wine, vinegar and acetic acid;

2. nutrition and care in nurseries, institutions for the collective accommodation of children and youth and institutions of social care for the accommodation of certain categories of persons;

3. health examinations, treatment and care of the sick people and jobs of keeping hygiene in health institutions and other forms of performing health activity, especially in the wards with the increased risk of infection;

4. providing hygienic care and beautification of face and body, jobs of making non-medical aesthetic interventions which violate skin integrity as well as on jobs of the production of medicaments and cosmetic devices.

Persons who during schooling perform compulsory practice at mentioned jobs must meet the conditions in terms of health ability set by regulations about the protection of citizens from contagious diseases (article 24 in Law on the protection of citizens from contagious diseases, „Official Herald of Serbia“, no. 125/2004).

Entrepreneurs who perform the mentioned activities are obliged to enable the compulsory health examinations of certain categories of their employees in the terms and in the manner set by law. They must bear the expenses of such examinations and to keep sanitary booklets in business premises where the activity is performed, as the proof of the health conditions of the employees.

Health examinations are performed before the employment, i.e. before the beginning of the compulsory practice at those jobs and every six months but according to epidemiological indications - in the period shorter than six months.

Health examinations of the persons employed at jobs of health examinations, treatment and care of the patients and the jobs of keeping hygiene in health institutions and other forms of health protection are performed before the employment, i.e. before the beginning of the compulsory practice at those jobs and every 12 months but according to epidemiological indications - in the period shorter than 12 months (article 10 in Rule-book on compulsory health examinations of certain categories of employees, other persons and bacteria carriers, „Official Herald of Serbia“, no. 20/2006, 27/2006).

The head-office has a multiple significance, primarily a business and fiscal one: for fulfilling fiscal liabilities; for setting the local authorities of court and administrative organs in the lawsuit, executive and administrative procedure where the entrepreneur participates; setting the local authority of the organ for performing the supervision over the legality of entrepreneur's work; setting the nationality of an entrepreneur; setting the applicable law which will be applied on the contract, according to the rules of the international law and the like ${ }^{26}$.

\footnotetext{
Mihajlović, P. Osnivanje preduzetnika, Pravo i privreda, Udruženje pravnika u privredi, Beograd, 2007, vol. 44 (5-8), pp. 993-1007.
} 


\section{Activity}

Law on economic enterprises in article 4, paragraph 1 stipulates that the economic enterprise may perform all other activities which are not forbidden by law regardless they are set by the constituent act, i.e. statute and article 4, paragraph 2 stipulates that a special law may condition the registration or performing of a certain activity by issuing the prior permission, agreement or another act of a competent authority.

An entrepreneur may perform all activities which are not forbidden by law and for which he meets set conditions, including old and artistic crafts and jobs of handicrafts.

For the jobs in economy the minister determines the jobs which are in terms of this law regarded as old and artistic crafts, i.e. jobs of handicrafts, the manner of certifying them and keeping the special files of issued certificates (article 88 in LEE).

In connection with it, there was passed the Rule-book about determining the jobs which are regarded as old and artistic crafts, i.e. jobs of handicrafts, the manner of certifying them and keeping the special files of issued certificates, „Official Herald of Serbia“, no. 56/2012.

If an entrepreneur wants to enter in the register as a predominant activity the one which may be performed only on the basis of the prior permission, agreement or another act of a competent authority, he is obliged to submit such permission, agreement or another act of a competent authority at submitting the application for entering of the activity in the Register (for example, production, transport, distribution, processing and storage of materials which are dangerous and harmful for the health of people and environment, jobs of the representative in insurance, private practice, production, transport and repair of weapons).

According to the provision of article $88 \mathrm{LEE}$, it is set that the provisions of article 4 in this law about the enterprise's activities are applied on the entrepreneur's activity.

For the entering in the register, an entrepreneur does not submit the certificate of competent inspection institutions about meeting the conditions in terms of the space where the activity is performed, except when it is set by a special law that it is necessary to supply such certificate for the registration and performing a certain activity.

The registrar of economic entities passed the Opinion about the registration of the predominant activity on 01.02.2012, where he mentioned that Law on economic enterprises, article 4, paragraph 1 stipulates that an economic enterprise has the predominant activity and it may perform all other activities which are not forbidden by law, no matter they are set by the constituent act, i.e. the statute. In article 4, paragraph 2 it is stipulated that a special law may condition the registration or performing certain activity by issuing a prior permission, agreement or other act of a competent authority.

Taking into consideration the mentioned provision in Law on economic enterprises, economic entities submit for entering in the Register which is kept at Agency for trade registers only one, predominant activity and other activities are presumed by the Law itself that economic entities may perform them if they get a prior permission, agreement or other act of a competent authority if it is set by a special law.

On the other hand, if an economic entity wants to enter in the Register which is kept at Agency for trade registers as the predominant activity that activity which may be performed only on the basis of the prior permission, agreement or other act of a competent authority, it is obliged to submit that permission, agreement or other act of a competent authority at submitting the application for entering that activity in the Register (for example, production, transport, distribution, processing and storage of materials which are dangerous and harmful for health of people and environment, jobs of banks, jobs of insurance companies). Thus, for example, pursuant to article 52, paragraph 1, item 5 in Law on transport in road transportation, an entrepreneur will be fined with 150.000 to 500.0oo RSD for the offence if he performs the taxi transport and his predominant activity is not the taxi transport or if he is not registered in the Register of economic entities for performing the activity of taxi transport or if he does not have the permission of a competent authority in the local government for performing the taxi transport.

The provision in article 88 in LEE, it is set that the provision of article 4 in this law about enterprise's activity is applied to the activity of the entrepreneur.

The economic entity, which wants to enter in the Register which is kept at Agency for trade registers, does not submit the certificate of competent inspection institutions about meeting the conditions in terms of space where the activity is performed, except when it is regulated by a special law that it is necessary to supply such certificate for the registration and performing of a certain activity.

It results from the given facts that economic entities may enter in the Register only one, predominant activity because it is allowed on the basis of Law on economic enterprises to perform other activities, but the economic entity must take care about meeting the conditions for performing such activities.

Besides that, neither the provisions of Law on economic enterprises nor the provision in Law on foreign trade business transactions do not state the obligation or the possibility of registering the data about performing the foreign trade transactions and services in foreign trade and in accordance to the 
Register of economic entities does not register these data from 01.02.2012. So, performing of both the predominant and side activities in the foreign trade transactions are not conditioned by the registration in the Register of economic entities ${ }^{27}$.

Nevertheless, in the practice, when one applies for getting work (public procurement) he must submit the proof that the entrepreneur has a registered certain activity. If he wants to apply for getting a few such works, he must submit the proof that he has all those activities registered and it is not possible because only one activity is registered, the one which is named as the predominant activity. Economic enterprises may achieve that by submitting their founding Act or the statute because activities are given in these acts by mentioning other activities which the enterprise will perform besides the predominant activity. But, the entrepreneur may not submit the funding Act or the statute because these acts are not necessary and they may not be brought in the procedure of the entrepreneur's registration. What is left to entrepreneurs is by registering the separate place where they perform the activity (apart from the head-office), when registering the separate place he should state in the registration application that they will perform some other activity at the separate place and not the one which the entrepreneur registered as the predominant activity. In such way, the proof is ensured - the act of registering a few activities and not only the one which is named as the predominant activity ${ }^{28}$.

Registering of the predominant activity may be important at classifying entrepreneurs into groups for the tax bases. The law on detailed conditions, criteria and elements for lump taxing of tax-payers on incomes from individual activity, "Official Herald of Serbia”, no. 65/2001, 45/2002, 47/2002, 91/2002, 23/2003, 16/2004, 76/2004, 31/2005, $25 / 2013,119 / 2013,135 / 2014$, regulate seven groups for establishing the tax base. The level of lump taxing will depend on the type of activity.

Besides that, it is prescribed in the legal system that some legal norms are in effect according to the predominant activity. For example, special collective agreements are signed according to the type of the predominant activity for all whose predominant activity is set by that collective agreement. It means that the rights of the employees set by that collective agreement will be applied to all employers in that activity.

Some activities which an entrepreneur may not perform are set by special laws. An entrepreneur

\footnotetext{
Serbian Business Registers Agency/SBRA: Database of enterprises and entrepreneurs, available at: www.apr.gov.rs accessed on February 05, 2016.

28 Stefanović, Z. Pravni položaj i aktuelna pitanja obavljanja delatnosti u statusu preduzetnika, Pravni instruktor, broj 68, stručni komentar elektronske baze propisa Paragaf Lex, Paragraf Lex doo Beograd, 2014.
}

may not perform the job of insurance, job of direct representation in customs procedure, job of line transport of passengers in road transportation, the activity of wholesale transactions with medicaments and medical devices, the activity of producing weapons and military equipment and the like. Bearing in mind that the entrepreneur is liable with personal assets for all liabilities and that, for example, a member of the company with limited liability is liable only for the liabilities of the enterprise up to the level of the subscribed but nor entered share as well as that the minimum cash basic capital for founding of company with limited liability is 100 RSD, there may arise the question of the justification of the prohibiting the entrepreneur to perform certain activities.

\section{Entrepreneur's assets and responsibility for liabilities}

Law on economic enterprises does not regulate what is included in the entrepreneur's assets. The concept of assets is regulated by civil-legal regulations.

The assets are a set of all subjective property rights of a person. The subjects of assets are: real rights, intellectual property rights (copyrights and rights of industrial property), rights of a person (if they are expressed in the form of the property) and laws of obligations (except those which cannot be expressed in money).

Each legal entity has one property and it is, by rule, inseparable from him ${ }^{29}$.

Objects of property rights may be: things, actions, personal property and intellectual property. Legal entities are in property-legal relation in terms of these objects.

The question is about the material part of the nature in human rule on which there is the subjective property right. The material part of nature, determined as an object, must meet physical and legal hypotheses. The physical hypothesis means that a part of nature may be in the rule of a man and the legal hypothesis demands that on that part of material nature there may be gained the real right or some other subjective property right.

Actions are active or inactive human behaviors for which the debtor is liable to the creditor based on some contractual obligations. They may consist in giving, acting, not acting or suffering. Actions are the object of contractual obligations whilst things are the object of proprietary relations.

Personal rights are the rights of the owner of personal property, like: right on life, health, freedom, honour, respect, body, spiritual and moral integrity, identity, privacy, name, person, voice. These rights

Pound, R. Jurisprudencija (ISBN 86-495-0166-4), tom II, Službeni list SRJ — CID, Beograd-Podgorica, 2000. 
are in one part protected by property law only if they can be expressed in the form of property.

Intellectual rights are the creations of human mind, which as their objects have copyrights and the right on industrial property (patent, sample, model, stamp, geographical origin and the like). These rights have the property-legal component (right to exploit a work or invention) besides the moral component ${ }^{30}$.

Property-legal relation is the relation between title holders of the subjective property right and the persons against whom these authorizations are directed, i.e. persons who are liable. The property-legal relation includes the authorized party (titular rights) and the persons against whom are directed the authorizations of the title holder of the subjective right, i.e. persons who are liable. Thus, a car owner has the subjective real right from which there results the obligation of holding, usage and managing with that thing. The property right imposes the liabilities of all persons. Contractual obligation appears between the creditor and the debtor. The creditor is authorized to ask from the debtor to fulfil the obligation and the debtor has to fulfil the obligation completely ${ }^{31}$.

For all liabilities which appear in connection with performing his activity, the entrepreneur is liable with his whole assets and the assets also include the assets which he obtains in relation to performing the activity. Legal practice: "The assets of a physical person who is an entrepreneur include rights, claims and funds obtained through the activity for which the shop is registered, but also the rights, claims and funds obtained outside it, from other materially legal relations. The assets of the person are burdened by liabilities which he took over in connection with performing the registered activity, but also the liabilities which were taken over beyond it", from the decision of District Commercial Court, Pž. 9249/07 on 03.04.2008).

In comparative law ${ }^{32}$ : The proprietor is personally responsible for all business losses and must bear them to the full extent of available personal resources. The proprietor is personally liable for all business liabilities. In contrast with a corporate shareholder or a limited partner, a proprietor carries a financial risk that is not limited to his or her investment in the enterprise but may extend to all personal assets, including the proprietor's home, car, furniture, and similar property.

\footnotetext{
30 Marković, V. Assets,Net Assets (Equity) and the Stated Capital of the Company, Zbornik radova međunarodne naučne konferencije „Financial reporting Function of the corporate governance", Singidunum University, Belgrade, DOI: 10.15308/finiz-2014-94-97, 2014, pp. 94-97.

Babić, I. Građansko pravo, Knjiga 1. Uvod u građansko pravo (ISBN 978-86-519-1028-2), JP Službeni glasnik i Fakultet za evropske pravno-političke studije, Beograd - Novi Sad, 2011.

32 Moye, J. The Law of Business Organizations. Cengage Learning, 2004.
}

The owner is inseparable from the sole proprietorship, so he/she is liable for any business debts; also called Proprietorship ${ }^{33}$.

The responsibility for the liabilities which appeared in relation to performing the activity is personal, direct and unlimited, without the possibility of its limitation.

The responsibility for mentioned liabilities does not stop by deleting the entrepreneur from the register.

The fact that an entrepreneur is deleted from the register of economic entities is not legally relevant for the responsibility based on ensued property liabilities in relation to performing the activity of a physical person who was registered as an entrepreneur. An entrepreneur does not have the capacity of a legal entity; the physical entitiy who is registered as an entrepreneur has the party and legal capacity. Consequently, when an entrepreneur is deleted and he loses the capacity of an entrepreneur, the responsibility for ensued liabilities of the physical person who was registered as an entrepreneur does not stop (See the decision of Commercial Court of Appeals, Pž. 424/2012 on 10.09.2012. „When an individual entrepreneur shop is deleted from the register, there does not stop the authorization which a physical person gave to a lawyer" - from the decision of Commercial Court of Appeals Pž. $893 / 2013$ on 21.02.2013).

As the responsibility of an entrepreneur for the liabilities which ensued in relation to performing the activity does not stop by deleting the entrepreneur from the register of economic entities, there may be put a question: when do those liabilities stop? The answer to this question is that the responsibility for the entrepreneur's liabilities stops when the entrepreneur fulfils his liabilities or when there appears some other legal reason for the cessation of liabilities (settlement, compensation, debt repudiation, novation, merging, impossibility of fulfillment, expiration and the like) ${ }^{34}$.

An entrepreneur loses his capacity of an entrepreneur by being deleted from the register of economic entities which is done because of the cessation of performing theactivity. Theentrepreneur stops performing the activity by notice of withdrawal or by operation of law. He stops work by operation of law in case when his business account in a bank is blocked for more than two years, on the basis of the request for deleting the entrepreneur from the register submitted by National bank of Serbia or Tax administration. There may be put a special question of the consequences on a physical person because of deleting the status of an entrepreneur by operation of law because of blocked business account for more

\footnotetext{
Masoom, K. The Entrepreneur's Dictionary of Business and Financial Terms. PartridgeIndia, 2013.

34 Babić, I. Leksikon obligacionog prava (ISBN 978-86-7549691-5), Službeni glasnik, Beograd, 2008.
} 
than two years (pursuant to article 91, paragraph 6 , item 3- Law on economic enterprises). The consequences are that a concrete physical person, whose status of an entrepreneur was deleted, may not perform the activity and all liablities and debts remain for that physical person. In that way, the increasing indebtedness of citizens ensues in that way. A separate problem in the impossibility of an entrepreneur's bankruptcy in our legal system. The solution of the mentioned problem could be the introducing of the individual bankruptcy in our legal system ${ }^{35}$. Besides that, our legal system did not consistently carry out the principle of the property oneness of and entrepreneur. When there is carried out the forced execution on an entrepreneur's assets by blocking the current account, the execution is carried out only on current accounts which belong to the entrepreneur, i.e. on current accounts which he opened for performing the activity in the status of an entrepreneur. These accountsare identified through the register number and tax identification number and it does not enable the identification of his personal accounts which are not used for performing the activity. It is possible that the forced execution be demanded also on private accounts of an entrepreneur - on those which he uses as a physical person and not for performing the activity, but those accounts will not be identified in the procedure of forced execution and they will not be blocked if forced execution was asked only on the accounts which are identified through the register number and tax identification number of the entrepreneur.

Law on payment operations, „Official Herald of FRY“, no. 3/2002, 5/2003 and „Official Herald of Serbia“, no. 43/2004, 62/2006, 111/2009 and 31/2001, in article 46 , paragraph 3 there are the prohibitions which set that economic entities cannot fulfil their liabilities by contracting the change of the creditor or the debtor, by compensation or in another way if their current accounts are blocked. This is valid for entrepreneurs but not for their liabilities which did not appear by performing the activity. Even if his personal current account is blocked, the prohibition of signing the mentioned contracts does not apply on him if he signs them as a physical person and not as an economic entity, i.e. an entrepreneur if there are no liabilities which appeared by performing the activity as an entrepreneur. The oneness of property makes possible for the rights and obligations acquired by performing the activity to outlive the very status of an entrepreneur. The fact that an entrepreneur is deleted from the register does not affect the obtained rights and obligations while he had that status. The cessation of the status of an entrepreneur does

\footnotetext{
Marković, V. Brisanje preduzetnika po sili zakona usled blokade poslovnog računa, Pravo i privreda, Udruženje pravnika u privredi, Beograd, 2014, vol. 51(1-3), pp. 258-267.
}

not lead to any succession because the rights and obligations are already based in favour of the person who had the status of an entrepreneur. This is valid for property rights and obligations which do not need any special licence (permission, agreement) for performing the activity. Nevertheless, if we talk about rights of obligations which may be based only in favour of (to the debt of) the person who has a certain licence to perform the activity and if we talk about the non-cash obligation which may be fulfilled only if there is a licence for that, when there is the loss of the status of an entrepreneur, a physical person who is no longer registered for performing the activity does not have the right to fulfil such obligations but he may be liable for the damage compensation. Unlike such non-cash liabilities which are taken over only on the basis of the licence, if we talk about the non-cash liabilities for which a licence is not needed or about cash liabilities, the loss of the status of an entrepreneur does not affect their existence and the obligation of fulfillment ${ }^{36}$.

In the practice, there may be put the question of the responsibility of spouses entrepreneurs if their mutual family household is maintained by the income gained by performing the entrepreneur's activity. In conncection with it, court practice has the following opinion: „Spouses are severally responsible for the loan which was given to one of the spouses, who acted in the capacity of an entrepreneur, if their mutual household was maintained by the income gained by the entrepreneurship activity“ — from the verdict of Court of Appeals in Novi Sad, Gž. $615 / 2012$ on 18.10 .2012 .

There is specially settled the responsibility of the household members for tax liabilities of entrepreneurs. Namely, for the tax on the income from independent activity there subsidiary guarantee all adult household members of the taxpayer, who make up the entrepreneur's household at the moment when the liability appeared.

Also, the person who, with or without the compensation, takes over a part or the whole assets with which the entrepreneur performs his activity, guarantees solidary for the liabilities which appeared by performing theactivity beforetaking overtheassets up to the level of the value of taken-over assets and the entrepreneur who stops performing the activity is obliged to fulfill all his tax liabilities which appeared during performing the activity, before deleting from the legitimate register (article 157, paragraph 2 and 3 in Law about tax on citizens' income, „Official Herald of Serbia“, no. 24/2001, 80/2002, 135/2004, 62/2006, 65/2006, 10/2007, 7/2008, 7/2009, 31/2009, 44/2009, 3/2010, 18/2010, 4/2011, 50/2011, 50/2011,

\footnotetext{
36 Stefanović, Z. Pravni položaj i aktuelna pitanja obavljanja delatnosti u statusu preduzetnika, Pravni instruktor, broj 68, stručni komentar elektronske baze propisa Paragaf Lex,
} Paragraf Lex doo Beograd, 2014. 
91/2011 (Decision of Constitutional court), 7/2012, 93/2012, 114/2012 (Decision of Constitutional court), 8/2013, 47/2013, 48/2013, 108/2013, 6/2014, 57/2014, $68 / 2014,5 / 2015)$.

There may be put the question of the responsibility of inheritors for the entrepreneur's liabilities in case of his death or the loss of working ability. By the provision in article 97, paragraph 7 in LEE it is set that in the case of death or the loss of working ability of the entrepreneur. the inheritor i.e. a member of his family household (spouse, children, adopted children or parents), who is at the same time a physical person able to work, may continue performing the activity on the basis of the decision about the inheritance or the mutual agreement about the continuation of performing the activity, signed by all inheritors, i.e. the members of family household. The person who continues the activity in the capacity of the inheritor is obliged, within 30 days upon the death of the entrepreneur, to report the continuation of performing the activity to the register in accordance to law about the registration of economic entities.

It results form the mentioned facts that if within 30 days upon the death of the entrepreneur an inheritor, i.e. a member of his family household informs the registar that the activity is continued, in that case he enters rights and liabilities which the former entrepreneur had and, consequently, he is responsible for all entrepreneur's liabilties by his assets. In that case, there is not the cessation of the continuity in performing the activity by the inheritor and the person - the new entrepreneur is responsible for all rights and liabilities of the former entrepreneur.

If performing the entrepreneurship activity is not continued in the mentioned way, but the cessation deletion of the entrepreneur is registered, in that case the inheritors of the entrepreneur are responsible for the entrepreneur's liabilites according to the rules of inheritance, up to the level of the hereditary share. (Commercial Court of Appeals - Questions and answeers - working material - from XX conference of commercial courts in The Republic of Serbia, Zlatibor, September 2012).

\section{Instead of the conclusion}

In the stage when the draft of Law on economic entreprises from 2005 was being created, by this law there was not settled an individual entrepreneur, which comprised passing a separate law. But, by passing the law, the legal status of an individual entrepreneur was yet principally settled by this law and the separate law was not passed. At the same time, the arguments for this approach were not given to the scientific and professional public.

Bearing in mind all that was written about the legal position of an individual entrepreneur, we suggest that in the future changes of the legislation, the following facts should be taken into account:

The first problem in the legal settlement of an individual entrepreneur is the terminology which is not in accordance with the juridical terminology from comparative law. In our law, the juridical term is „an entrepreneur", which is a too wide and unspecified term because in economic science this term represents the genus concept for the individual and collective entrepreneurship, for the individual who takes over the business undertaking in order to ensure the products or services on the market for the purpose of making profit.

There should be analyzed all activities which now entrepreneurs may perform as they are forbidden by separate laws; one should evaluate the reasons for and against and work on eliminating the prohibitions and favouring legal entities.

The bunkruptcy of an individual entrepreneur, i.e. the individual bankruptcy of a physical person should be regulated by law.

Work on passing the separate legislature in the field of the individual entrepreneurship, especially on passing and changing the laws which would regulate crafts industry (including old crafts and the jobs of handicrafts), a free profession as well as the agricultural activity in a comprehensive, detailed, clear and mutually coordinated manner and all with the aim to encourage the development of the individual entrepreneurship and the increase in the number of individual entrepreneurs.

\section{References}

1. Babić, I. Građansko pravo, Knjiga 1. Uvod u građansko pravo (ISBN 978-86-519-1028-2), JP Službeni glasnik i Fakultet za evropske pravno-političke studije, Beograd — Novi Sad, 2011.

2. Babić, I. Leksikon obligacionog prava (ISBN 978-86-7549691-5), Službeni glasnik, Beograd, 2008.

3. By-law on detailed conditions, criteria and elements for lump taxation on the income from the independent activity, „Official Herald of Serbia“, no. 65/2001, 45/2002, 47/2002, $91 / 2002$, 23/2003, 16/2004, 76/2004, 31/2005, 25/2013, 119/2013, 135/2014.

4. Carić, S., Vitez, M. i Veselinović P. J. Privredno pravo (ISBN 86-84613-38-4), Privredna akademija, Novi Sad, 2006.

5. Cohen, W. A. Entrepreneur and Small Business Problem Solver. John Wiley \& Sons, 2006.

6. Clark, J. i Owen E. ed. Dictionary of International Accounting Terms. Global Professional Publichi, 2001.

7. Clark, J. i Owen E. ed. Dictionary of International insurance and finance terms. Global Professional Publichi, 2001.

8. Chambers of Commerce Euregio Meuse-Rhine/ CCEMR: Database of legal entities, available at: http:// www.euregiochambers.eu/legal-enities/germany/soleproprietorship.html, accessed on October 03, 2016.

9. Chambers of Commerce Euregio Meuse-Rhine/ CCEMR: Database of legal entities, available at: http:// 
www.euregiochambers.eu/legal-entities/belgium/soleproprietorship.html, accessed on Octobre 03, 2016.

10. Commercial Register from Germany/CRG: Legal forms in Germany, available at: http://www.commercial-register.com/ legalformsgermany.html accessed on October 03, 2016.

11. Dabić, Lj. Individualni preduzetnik kao privredni subjekt i kao poseban pravnoorganizacini oblik, Pravo i privreda, Udruženje pravnika u privredi, Beograd, 2005, vol. 42(5-8), pp. 164-185.

12. Dabić, Lj. Pojmovno određenje i svojstva slobodnih profesija, Pravni život, Udruženje pravnika Srbije, Beograd, 2008, vol. 57(12), pp. 473-489.

13. Das regionale Wirtschaftsportal/RW: Rechtsformeinzelunternehmen, available at: http://www.business-on.de/ rechtsform-einzelunternehmen-kleingewerbe-kaufmannvorteile-rechte-_id accessed on October 03, 2016.

14. Gill, J. Business Law for the Entrepreneur. Arima Publishing, 2005.

15. Gruenden: Step by step to your own company, Legal structure - sole proprietorship, available at: http://www. gruenden.ch/en/founding-process/preparation/legal-forms/ sole-propretorship / accessed on October 03, 2016.

16. Law on agriculture and rural development, "Official Herald of Serbia”, number 41/2009 i 10/2013- other law.

17. Law on economic enterprises, Narodne novine Hrvatske, 111/1993, 34/1999, 52/2000, 118/2003, 107/2007, 146/2008, 137/2009, 125/2011, 152/2011, 111/2012, 68/2013.

18. Law on economic enterprises, „Official Herald of Serbia“, number 36/2011, 99/2011, 83/14, 5/15.

19. Law on payment operations, „Official Paper of FRY“, number 3/2002, 5/2003 and "Official Herald of Serbia", no. 43/2004, 62/2006, 111/2009 - another law 31/2011.

20. Law on protection of the population from contagious diseases, „Official Herald of Serbia“, number 125/2004.

21. Law on tax on citizens' income, „Official Herald of Serbia“, number 24/2001, 80/2002, 135/2004, 62/2006, 65/2006, 10/2007, 7/2008, 7/2009, 31/2009, 44/2009, 3/2010, 18/2010, 4/2011, 50/2011, 91/2011 (Decision of Constitutional court), 7/2012, 93/2012, 114/2012 (Decision of Constitutional court), 8/2013, 47/2013, 48/2013, 108/2013, 6/2014, 57/2014, $68 / 2014,5 / 2015$.

22. Law on transport in road transportation, "Official Herald of Serbia”, number 46/95, 66/2001, 61/2005, 91/2005, 62/2006, $31 / 2011$.

23. Law on value added tax, „Official Herald of Serbia“, number 84/2004, 86/2004, 61/2005, 61/2007, 93/2012, 108/2013, 6/2014, 68/2014, 142/2014, 5/2015.

24. .Marković, V. Brisanje preduzetnika po sili zakona usled blokade poslovnog računa, Pravo i privreda, Udruženje pravnika u privredi, Beograd, 2014, vol. 51(1-3), pp. 258-267.

25. Marković, V. Assets,Net Assets (Equity) and the Stated Capital of the Company, Zbornik radova međunarodne naučne konferencije "Financial reporting Function of the corporate governance“, Singidunum University, Belgrade, DOI: 10.15308/finiz-2014-94-97, 2014, pp. 94-97.

26. Masoom, K. The Entrepreneur's Dictionary of Business and Financial Terms. PartridgeIndia, 2013.

27. Moye, J. The Law of Business Organizations. Cengage Learning, 2004.
28. Mihajlović, P. Osnivanje preduzetnika, Pravo i privreda, Udruženje pravnika u privredi, Beograd, 2007, vol. 44 (5-8), pp. 993-1007.

29. Milenović, D. Entrepreneur (Individual Tradesman) in Our Law, Pravni život, Udruženje pravnika Srbije, Beograd, 2002, vol. 51(11), pp. 81-92.

30. Pound, R. Jurisprudencija (ISBN 86-495-0166-4), tom II, Službeni list SRJ - CID, Beograd-Podgorica, 2000.

31. Rule-book on compulsory health examinations of certain categories of employees, other persons and carriers, "Official Herald of Serbia", no. 20/2006, 27/2006.

32. Rule-book on detailed conditions for performing health activity in health institutions and other forms of healt service, "Official Herald of Serbia", no. 43/2006, 112/2009, 50/2010, 79/2011, 10/2012, 119/2012, 22/2013.

33. Rule-book on determining the jobs which are regarded as old and art crafts i.e. the jobs of handicrafts, the manner of certifying them and keeping special files of issued certificates, "Official Herald of Serbia", no. 56/2012.

34. Rule-book on general sanitary conditions which must be fulfilled by the facilities that subject to the sanitary supervision, „Official Herald of Serbia“, no. 47/2006.

35. Rule-book on minimal technical conditions for trade at purchasing places, „Official Herald of Serbia“, number 72/2011.

36. Serbian Business Registers Agency/SBRA: Database of enterprises and entrepreneurs, available at: www.apr.gov.rs accessed on February 05, 2016.

37. Serbian Business Registers Agency/SBRA: Odnosi s javnošću, available at: http://www.apr.gov.rs/Односисјавношћу/Вeсти.aspx accessed on April 08, 2015.

38. Spadaccini, M. Business Structures: Forming a Corporation, LLC, Partnership, Or Sole Propretorship. Entrepreneur Press, 2007.

39. Spirović Jovanović, L. Preduzetnik i privatni preduzetnik u našem pravnom sistemu, Ekonomski anali, Ekonomski fakultet Univerziteta u Beogradu, 1999, vol. 43(141), pp.185193.

40. Spirović Jovanović, L. Trgovac pojedinac, preduzetnik ili individulani privrednik, Pravni život, Udruženje pravnika Srbije, Beograd. 1996, vol. 45(11), pp. 145-157.

41. Stefanović, Z. Pravni položaj i aktuelna pitanja obavljanja delatnosti u statusu preduzetnika, Pravni instruktor, broj 68, stručni komentar elektronske baze propisa Paragaf Lex, Paragraf Lex doo Beograd, 2014.

42. Vasiljević, M. Kompanijsko i trgovinsko pravo (ISBN 97886-519-0046-7). Pravni fakultet Univerziteta u Beogradu i JP Službeni glasnik Beograd, 2008.

43. Vasiljević, M. Vodič za primenu Zakona privrednim društvima (ISBN 978-86-83437-96-2), Intermex, Beograd, 2011.

44. Vukadinović, R. Međunarodno poslovno pravo (ISBN 97886-88987-03-5). Udruženje za evropsko pravo, Kragujevac, 2012.

45. Zakon o gospodarskih družbah, Uradni list Republike Slovenije, 42/2006.

46. Zakon za trgovskite društva, Službeni vesnik na Republika Makedonija, 28/2004, 84/2005, 71/2006, 25/2007, 87/2008, 17/2009, 23/2009, 42/2010, 48/2010. 